\title{
Perceptions of Buddhism among Professionals in Nepal
}

\author{
Mahendra Kumar Shakya* \\ Lumbini Buddhist University, Nepal
}

\section{Abstract}

Prince Siddhartha, who later became the Buddha, was born in the city of Lumbini in Nepal circa 623 BC. His spiritual guidance inspires millions of followers and practitioners globally. The teachings of the Buddha, who throughout his life preached about integrity and morality, could be valuable in promoting ethics and integrity and could also play an influencing role in the current drive of the Nepalese government to create a prosperous nation. Thus, understanding the perceptions of the development professionals and the intellectuals of Nepal towards this system of philosophy would be critical to understand not only the current status of Buddhist teachings in Nepal but also how this system of thought could be diverted for the purposes of nationbuilding.

To understand the existing knowledge and perceptions of the professionals, an exploratory survey was carried out in October 2018 with questionnaires developed using Google Forms. The link was shared among 250 professionals and the first 100 responses received online were tabulated and analyzed. The study found that more than two-thirds of the respondents do not have even a

\footnotetext{
* Corresponding should be addressed to Mr. M. K. Shakya, Lumbini Buddhist University, Nepal
}

Email: shakyamahendra@hotmail.com

(D) https://orcid.org/0000-0002-8463-1242

(Received $4^{\text {th }}$ July 2019; Revised 10th December 2019; Accepted 30th December 2019) (C) OUSL) 
basic knowledge about the Buddha's teachings and practices, which would comprise the teaching disseminated through the texts such as The Dhammapada, Jataka Stories, and the philosophical foundations of the Four Nobel Truths, the Nobble Eightfold Path, and Meditation. Some of these professionals illustrated the importance of including the teachings of the Buddha in the school curriculum and offering meditation as an extracurricular activity.

Key words: Four Noble Truth, Noble Eightfold Path, Jataka Stories, Dhammapada

\section{Introduction}

Prince Siddhartha, who later became the Buddha, was born in the city of Lumbini in Nepal circa 623 BC. His spiritual guidance inspires millions of followers and practitioners globally. The religion is practiced today in Cambodia, Thailand, Myanmar (Burma), Bhutan, Sri Lanka, Laos, Mongolia, Japan, China, Singapore, Taiwan, Vietnam, Macau, South Korea, and Malaysia. China is the country with the largest population of Buddhists. As it does not require any formal "conversion", Americans from every ethnicity, nationality and religious tradition incorporate Dhamma practices into their normal routines and traditions. Consequently, Buddhism is rapidly spreading in the USA these days.

\section{Buddhism in Ancient Nepal}

Buddha visited Kapilvastu the same year of his enlightenment with 20 thousand perfectly liberated monks (Sancrityayan, R. 2018, P: 91). While in Kapilvastu he is said to have demonstrated psychic powers, preached to his relatives including his father, king Sudhodhana and ordained some people including his son, Rahula. Theravada tradition is believed to be the oldest unbroken tradition that existed in Nepal from the time of the Buddha. Later, Emperor Ashoka sent nine missionary groups to different locations to spread the Dhamma (Dutt, 1966). A group 
missionary of monks led by Venerable Majjima came to Nepal and succeeded in propagating Buddhism (Ven. Sujano, 2008). In ancient Nepal, the Lichchavi period is regarded as the golden age where Buddhism flourished (Thapa, 2014). During the period Nepali princes married Song-Tsen Gampo and assisted in the introduction of Buddhism to Tibet.

Buddhism remained a dominant religion until the time of Jayasthiti Malla who ruled Nepal during the medieval period (around 1382 C.E.). He imposed the caste system in Nepal according to Manudharmasastra, a Hindu holy book (Ven. Sujano, 2008). He banned Buddhist culture and tradition and forced the celibate monks to disrobe and marry. Thus Buddhism continued to decline in the birth country of the Buddha because of the restrictions imposed by the state.

\section{Buddhism in Nepal today}

Nepal is a landlocked country with a population of 26.4 million. It enjoyed an official status of a Hindu kingdom until December 2007 when the interim constitution declared Nepal as a secular state. Now, all religions in Nepal by the constitution have equal opportunities to propagate. Despite this fact, Buddhist intellectuals have the view that the environment in Nepal is not supportive of Buddhism. They alleged that the government is interested in offering a positive impression to the international communities; however, in reality, the situation is much different (Udash, 2018). Nepal frequently claims to be the birthplace of the Buddha; however, it does not treasure the Buddha and his teachings (Paudel, 2018). According to him, the budget set aside for promoting Buddhism is inadequate. The budget allocated by the government to the Lumbini Buddhist University is proof of how the state is ignoring Buddhism. Hindus regarded the Buddha as the ninth incarnation of Lord Narayana and argue that Buddhism is a branch of Hinduism.

Nepal is blessed with many sites associated with the Buddha including Lumbini, Gotihawa and Tilaurakot, the birthplace of Shakyamuni, Krakuchhanda and Kanakmuni Buddha; therefore, 
Nepal has every potential of being benefitted from Buddhism. The teachings of the Buddha, who throughout his life preached about integrity and morality, could be valuable in promoting ethics and integrity and could also play an influencing role in the current drive of the Nepalese government to create a prosperous nation. At the time when corruption and lawlessness have become endemic in the country, the significance of Buddha's teachings has become even more relevant.

According to the chronicles of Buddhist history, Mauryan Emperor, Ashoka in his $20^{\text {th }}$ year of coronation visited Lumbini, erected pillar and released the peasants from all taxes. The pillar is an absolute evidence for the birthplace of the Buddha; despite the fact, many international devotees still have a misguided belief that India is the birthplace. Many a time Nepalese have united to globalize the message that Lumbini of Nepal is the birthplace of the Buddha. The most recent effort is the "Buddha was born in Nepal" campaign organized by the Nepalese youth and artists in Kathmandu on $3^{\text {rd }}$ March 2018. The organizers believed that around 100,000 people assembled in Tundikhel. The event was a historic one in terms of the biggest number of people coming together to proclaim the message that "Buddha was born in Nepal" simultaneously. On the occasion, they also recited 25 verses of The Dhammapada, a collection of the Buddha's aphorisms. The Campaign not only demonstrated solidarity for reclaiming Lumbini as the birthplace of the Buddha, it also laid a strong foundation for the Buddha to become a symbol of national unity.

In this regard, this researcher is of the view that the time has come for Nepal to cherish the Buddha and his teachings and reap the benefits of such acts. While claiming Nepal as the birthplace of the Buddha, the nation should also cherish the Buddha and his teachings. Nepal should understand that the best way of inheriting the legacy of the Buddha is to treasure and practice his teachings. Thus, understanding the perceptions of the development professionals and the intellectuals of Nepal towards 
this system of philosophy would be critical to understand not only the current status of Buddhist teachings in Nepal, but also how this system of thought could be diverted for the purposes of nation-building.

\section{Objectives}

The main objective of this study was to explore the level of understandings of Nepalese professionals about the fundamental teachings of the Buddha and their perception of how Nepal could benefit from the teachings.

Other specific objectives of the exploration are to draw attention of the national and international communities towards the survey findings, which could help promote Buddhist teachings and practices in Nepal and highlight the measures suggested by the respondents for the benefit of Nepal and her people.

\section{Methodology}

The relevant literature on the existing situation of Buddhism in Nepal was reviewed before developing the questionnaire. Consultations were made with knowledgeable persons while drafting and finalizing the questionnaires. The different templates available online were used to develop the basic questionnaires and they were pretested for technical validation. Because of its technical superiority, the questionnaire was developed using Google Forms with 3 multiple choices and 8 Yes/No type questions, one short and one long answer question on basic understandings of Buddhism. Five categories were provided in the section of age group, education level, and three (male, female and prefer-not-to-say) choices were offered on gender.

A list of professionals working in government and nongovernment organizations was prepared with their contact addresses using alumni directory, mailing lists, and staff contact details. The list included mostly the group of professionals this 
researcher came across in his 3 decades-long academic and professional life. The survey was conducted during October 2018 by sharing the digital link among 250 of these professionals, both male and female, through mobile phone, Facebook messenger, email and Whatapps and they were requested for their responses. Furthermore, as questionnaires included very basic features about Buddha's teachings, specifically the traditional Buddhists were not included in the survey. Care was exercised to increase the number of responses from female respondents to ensure gender balance. The name of the respondent was not asked; however, they were requested to provide an email address for further clarification. Regular follow-ups were made through telephones and messenger for timely responses. The responses received online from the first 100 respondents in each of the topics were tabulated and analyzed based on the frequency distributions. A Chi-square test was done to examine if the responses received from respondents with respect to education levels and age groups vary significantly or not. Likewise, the suggestions received were reviewed, classified and summarized.

\section{Limitations}

This study was conducted within a limited time and resource constraints. Due to this, the sample size had to be limited to 100.

\section{Result and Discussion}

Nepal is divided into three topographic regions and has a diverse culture with people representing different caste and ethnic groups. The survey link was shared with the group of professionals and the responses from the first 100 respondents were analyzed irrespective of region, caste, and ethnicity.

Among the respondents, 21\% were female and 79\% male, 93\% belonged to the age group above 30 years with a mean age of 48.5 years. Similarly, $82 \%$ of the respondents have the education level 
of Masters and above. The responses received in each of the topics have been discussed below.

\section{Knowledge of the life story of the Buddha}

This question was included to know if the subjects were familiar with the life story of the Buddha. The majority $(85 \%)$ of respondents ( $82 \%$ male and $95 \%$ female) have provided a positive answer and it did not vary significantly among the respondents with different age groups and education levels. Whereas 14\% have not read about the Buddha and one did not answer.

\section{Reading The Dhammapada}

The Dhammapada is considered to be a collection of the discourses of the Buddha delivered on various occasions, on various topics (Shakya, 1980). It is regarded as a guidebook for resolving the countless problems of everyday life; therefore, this is very important for every Buddhist to be familiar with the verses of The Dhammapada. Being simple and concise, The Dhammapada is usually the first book on Buddhism for both Buddhists and non-Buddhists interested in the study of the religion. Despite this, in the birthplace of the Buddha, only $18.0 \%(17.7 \%$ male and $19 \%$ female) of the professionals have studied The Dhammapada, whereas $81 \%$ ( $81 \%$ male and $80.9 \%$ female) have not read it and one percent did not answer. This varied significantly with the different educational and age groups having Chi-square values of 11.52 and 46.64 at d. f. 4 and p-value 0.05 respectively. More than $45 \%$ of the respondents within the age group above 60 years have provided a positive answer.

\section{Hearing about The Jataka Stories}

The Jataka Stories are a voluminous body of literature concerning the previous births of the Gautam Buddha in both human and animal form. There are 550 such stories that tell about the bravery and humanity of the Bodhisattva, the being attempting to fulfill the perfections to be the Buddha. Therefore, to understand Buddhism one must be familiar with The Jataka Stories. In the survey, only $27 \%$ ( $27.8 \%$ male and $23.8 \%$ female) mentioned that they have heard about The Jataka Stories, 
whereas $71.9 \%(68.35 \%$ male and $71.4 \%$ female) have never heard and were unaware about The Jataka Stories. The response varied significantly with educational and age groups with the Chisquare value of 11.83 and 80.74 at d. f. 4 and p-value 0.05 respectively. All of the subjects within the age group below 30 were found to be aware of The Jataka Stories. Three males and one female respondent did not reply.

Table 1. The responses received on the basic understanding of Buddhism.

\begin{tabular}{|c|c|c|c|c|c|c|c|c|}
\hline \multirow[b]{2}{*}{$\begin{array}{l}\text { S1 } \\
\text { No. }\end{array}$} & \multirow[b]{2}{*}{ Question } & \multicolumn{3}{|c|}{ Male } & \multicolumn{3}{|c|}{ Female } & \multirow{2}{*}{$\begin{array}{c}\text { Tota } \\
1 \text { Yes } \\
\text { (\%) }\end{array}$} \\
\hline & & $\begin{array}{l}\text { Yes } \\
\text { (\%) }\end{array}$ & $\begin{array}{l}\text { Nol } \\
\%)\end{array}$ & $\begin{array}{c}\text { Blank } \\
\text { (\%) }\end{array}$ & $\begin{array}{c}\text { Yes( } \\
\%)\end{array}$ & $\begin{array}{l}\text { Nol } \\
\%)\end{array}$ & $\begin{array}{c}\text { Blank } \\
(\%)\end{array}$ & \\
\hline 1 & $\begin{array}{l}\text { Studied the life story } \\
\text { of the Buddha }\end{array}$ & 65 & 13 & 1 & 20 & 1 & 0 & 85 \\
\hline 2 & $\begin{array}{lrr}\text { Have read } & \text { The } \\
\text { Dhammapada } & \\
\end{array}$ & 14 & 64 & 1 & 4 & 17 & 0 & 18 \\
\hline 3 & $\begin{array}{l}\text { Heard about } \text { The } \\
\text { Jatak Stories }\end{array}$ & 22 & 54 & 3 & 5 & 15 & 1 & 27 \\
\hline 4 & $\begin{array}{l}\text { Practiced Vipassana } \\
\text { meditation }\end{array}$ & 26 & 50 & 3 & 9 & 12 & 0 & 35 \\
\hline 5 & $\begin{array}{l}\text { Knowledge of The } \\
\text { Four Noble Truths }\end{array}$ & 36 & 42 & 1 & 14 & 6 & 1 & 50 \\
\hline 6 & $\begin{array}{l}\text { Knowledge of The } \\
\text { Noble Eightfold Path }\end{array}$ & 21 & 56 & 2 & 6 & 15 & 0 & 27 \\
\hline 7 & $\begin{array}{l}\text { Heard of the Five } \\
\text { Moral Precepts }\end{array}$ & 51 & 28 & 0 & 14 & 7 & 0 & 65 \\
\hline 8 & $\begin{array}{l}\text { The Buddha's } \\
\text { teachings to children }\end{array}$ & 75 & 4 & 0 & 19 & 2 & 0 & 94 \\
\hline
\end{tabular}

\section{Having the opportunity to practice Vipassana meditation}

Buddhism is primarily about the purification of the mind. Meditation with a strong moral ground is the means of gaining wisdom to purify the mind. Vipassana is an insightful form of meditation promoting self-awareness which was taught by the Buddha 2600 years ago. Vipassana techniques are non-sectarian and can be practiced by all, irrespective of caste, creed, religion or nationality (Singh, 1997). In Nepal, Vipassana meditation sessions of 10 days duration are offered in eight centers throughout the country (Budhanilakantha, Kirtipur, Itahari, Chitwan, Pokhara, Birgunj, Lumbini and Surkhet) with free food and boarding facilities. Likewise, Satipathan and other forms of 
meditation sessions are offered in many other centers. The enlightened one developed meditation entirely for the benefit of the humankind. Human life will definitely be incomplete if one does not experience meditation in one of these centers at least once (Shakya, 2019, P: 8); despite this, only 35\% (32.9\% male and $42.8 \%$ female) respondents mentioned that they had the opportunity of practicing Vipassana or other forms of meditation. $62 \%$ (63.3\% male and $57.1 \%$ female) have mentioned that they have not got the opportunity to be familiar with meditation. On the contrary, $75 \%$ of the undergraduates and $70 \%$ of those with doctorates were found to have practiced meditation. The number of respondents having the opportunity of practicing Vipassana and other forms of meditation varied significantly with education levels; however, it is non-significant among different age groups with Chi-square values of 94.0 and 8.79 at d. f. 4 and p-value 0.05 respectively.

Table 2. Response Based on Education Level

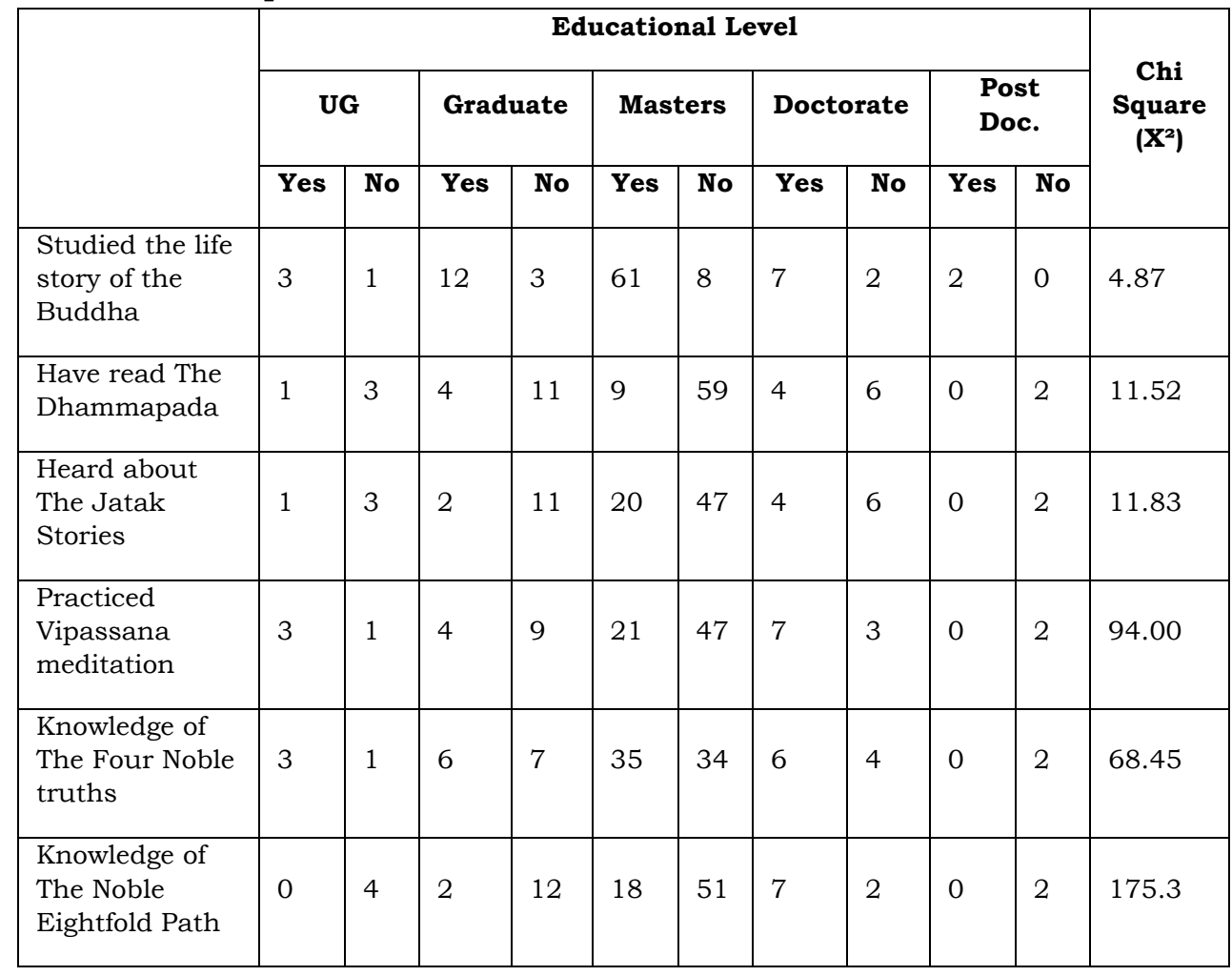




\begin{tabular}{|l|l|l|l|l|l|l|l|l|l|l|l|}
\hline $\begin{array}{l}\text { Heard about } \\
\text { the Five Moral } \\
\text { Precepts }\end{array}$ & 3 & 1 & 12 & 3 & 43 & 26 & 5 & 5 & 2 & 0 & 19.38 \\
\hline $\begin{array}{l}\text { The Buddha's } \\
\text { teachings to } \\
\text { children }\end{array}$ & 3 & 1 & 14 & 1 & 65 & 4 & 10 & 0 & 2 & 0 & 4.56 \\
\hline
\end{tabular}

Table value of Chi-square for a degree of freedom 4 at $5 \%$ level is 9.49

\section{Knowledge on the Four Noble Truths}

The Four Noble Truths include the truth of suffering, the truth of the origin of the suffering, the truth of the cessation of suffering and the truth of the path that leads to the cessation of suffering. It is the heart of Buddha's teachings. It is the truth Bodisatwa Siddhartha found on the full moon night of May. It is said that before understanding the Noble Truths clearly in 3 forms and 12 aspects, the Bodhisatwa Siddhartha did not claim to be the Buddha; therefore, the Four Noble Truths is the nucleus of teachings of the Buddha. Despite this, only 50 percent $(45.5 \%$ male and $66.6 \%$ female) mentioned that they have some knowledge of the Four Noble Truths. Whereas, 48\% (53.1\% male and $28.5 \%$ female) mentioned that they do not know the Noble Truths. Those having knowledge of the Four Noble Truths varied significantly with educational and age groups at d. f. 4 and pvalue 0.05 respectively. $75 \%$ of the undergraduates were aware of the Four Noble Truths; on the contrary, all of the postdoctorate subjects were unaware of the Truths. On the other hand, more than $72 \%$ of the respondents within the age group above 60 had knowledge of the Four Noble Truths. One male and one female did not respond. 
Table 3. Response Based on Age Groups

\begin{tabular}{|c|c|c|c|c|c|c|c|c|c|c|c|}
\hline \multirow{3}{*}{ Questions } & \multicolumn{10}{|c|}{ Age group } & \multirow{3}{*}{$\begin{array}{c}\text { Chi } \\
\text { Square } \\
\left(\mathrm{X}^{2}\right)\end{array}$} \\
\hline & \multicolumn{2}{|c|}{ Below 30} & \multicolumn{2}{|c|}{30 to 40} & \multicolumn{2}{|c|}{40 to 50} & \multicolumn{2}{|c|}{50 to 60} & \multicolumn{2}{|c|}{ Above 60} & \\
\hline & Yes & $\begin{array}{l}\mathbf{N} \\
\mathbf{0}\end{array}$ & Yes & No & Yes & $\begin{array}{l}\mathbf{N} \\
\mathbf{0}\end{array}$ & $\begin{array}{c}\text { Ye } \\
\text { s }\end{array}$ & No & Yes & No & \\
\hline $\begin{array}{l}\text { Studied the } \\
\text { life story of } \\
\text { the Buddha }\end{array}$ & 6 & 1 & 18 & 1 & 15 & 3 & 34 & 9 & 12 & 0 & 3.35 \\
\hline $\begin{array}{l}\text { Have read The } \\
\text { Dhammapada }\end{array}$ & 1 & 6 & 1 & 18 & 5 & 13 & 6 & 38 & 5 & 6 & 46.64 \\
\hline $\begin{array}{l}\text { Heard about } \\
\text { The Jatak } \\
\text { Stories }\end{array}$ & 7 & 0 & 5 & 13 & 7 & 11 & 11 & 32 & 4 & 6 & 80.74 \\
\hline $\begin{array}{l}\text { Practiced } \\
\text { Vipassana } \\
\text { meditation }\end{array}$ & 3 & 4 & 5 & 14 & 9 & 9 & 14 & 29 & 4 & 6 & 8.79 \\
\hline $\begin{array}{l}\text { Knowledge of } \\
\text { the Four } \\
\text { Noble Truths }\end{array}$ & 4 & 3 & 9 & 10 & 8 & 10 & 21 & 22 & 8 & 3 & 9.65 \\
\hline $\begin{array}{l}\text { Knowledge of } \\
\text { the Noble } \\
\text { Eightfold Path }\end{array}$ & 4 & 3 & 3 & 16 & 4 & 14 & 10 & 33 & 6 & 5 & 44.56 \\
\hline $\begin{array}{l}\text { Heard about } \\
\text { the Five Moral } \\
\text { Precepts }\end{array}$ & 5 & 2 & 11 & 8 & 12 & 6 & 26 & 18 & 11 & 1 & 10.76 \\
\hline $\begin{array}{l}\text { The Buddha's } \\
\text { teachings to } \\
\text { children }\end{array}$ & 7 & 0 & 17 & 2 & 17 & 1 & 42 & 2 & 11 & 1 & 0.68 \\
\hline
\end{tabular}

Table value of Chi-square for d. f. 4 at $5 \%$ level is 9.49

\section{Knowledge on the Noble Eightfold Path}

The fourth Noble Truth is the Noble Eightfold Path that one has to follow to attend Nibbana, the ultimate goal of Buddha's teaching. For purposes of simplicity, the Noble Eightfold Path is classified into morality, meditation, and wisdom. According to the Buddha, no one can attain Nibbana without following the 'Noble Eightfold Path'; therefore, it is regarded as the only exceptional path (ekaeno ayan maggo) to emancipation (Ven. Nyanatiloka, $1971)$. Only $27 \%(26.5 \%$ and $28.5 \%$ female $)$ mentioned that they have knowledge of the Noble Eightfold Path. Whereas, 71\% (70.8\% and $71.4 \%$ female) mentioned that they are not aware of the Noble Eightfold Path. The responses varied significantly with educational levels and age groups at d. f. 4 and p-value 0.05 respectively. All of the undergraduates and post-doctorate subjects were unaware of the Eightfold Noble Path whereas more 
than $77 \%$ of those with doctorates mentioned that they were aware of the Noble Path. Two male respondents did not answer.

\section{Knowledge of the Five Moral Precepts}

Morality is an integral part of the path to Nibbana and the five moral precepts include abstaining from: killing, stealing, sexual misconduct, telling lies and taking toxicants. These are the basic moral obligations for Buddhists that they are expected to follow them every day as a prerequisite to leading a decent life. 65 percent ( 64.5 and $66.7 \%$ female) of the respondents were aware of the 'Five Moral Precepts'. Whereas, 35\% (35.4 and 33.3\% female) did not know about them. The response varied significantly with educational levels and age groups. $75 \%$ of undergraduates, $80 \%$ of graduates and $100 \%$ of the post-doctorates knew about the five moral precepts. Similarly, $91.67 \%$ of the respondents within the age-group above 60 had knowledge of the moral precepts.

\section{The Buddha's teachings to the Nepalese children in schools}

The education system has a significant role in producing good and dedicated citizens. Early childhood education up to the secondary level is considered to be the most important in promoting ethical standards and moral values. The Buddhist intellectual Prof Dr. Bajra Raj Shakya in an interview with a National Buddhist bimonthly (2018) indicated that the education system in Nepal is not practical because it lacks in religious and cultural materials that are essential to make people moral, disciplined and responsible. Introducing moral education and meditation practices in schools could have a significant role in increasing the number of ethical, honest and patriotic citizens. Responding to the queries, 94 percent (95\% male and $90.5 \%$ female) of the respondents expressed the notion that children of Nepal should be provided with exposure to the teachings of the Buddha at school. As the children of the nation which is the birthplace of the Buddha, they should know about the Buddha and his teachings. Whereas, 6 percent (5\% Male and 1\% female) provided a negative answer. The respondents with different education levels as well as age groups had similar views with Chi- 
square values of 4.56 and 0.68 at d. f. 4 and p-value 0.05 respectively.

\section{Professionals' perceptions regarding Buddha's teachings in Nepal}

Nepal is blessed with many sites linked to the Buddha, including Lumbini; therefore, Nepal has every potential of benefiting from the legacy and the teachings of the Buddha. Almost all (99\%) of the respondents agreed that Nepal should be benefitted from the teachings of the Buddha. Nepalese youths should not ignore their cultural roots so they could prevent proselytization and promote age-old religious and cultural traditions. They suggested the ways in which Nepal as a nation could benefit from the teachings of the Buddha. They are as follows:

\section{Introduction of the Buddha's teachings to the school curriculum}

The majority of the respondents recommended the inclusion of the teachings of the Buddha to the school curriculum from the primary level. The potentials of Buddhism should be exploited in producing morally good and patriotic citizens. Some suggested that his teachings should be included in college-level also. The teaching materials should be prepared in simple and understandable language and offer insights into the fundamentals of Buddhism to students and the general public. Some respondents mentioned that the people from the birthplace of the Buddha should know and practice His teachings in daily life.

Some of the respondents also recommended including meditation as an extracurricular activity. Particularly, Anapana, breathing meditation should be introduced to children in schools. Likewise, few suggested introducing moral education with other religious teachings including the texts The Bhagawat Gita. 


\section{Nepal should utilize Buddha's teachings and practices to its mission of prosperity}

Many had the opinion that Nepalese should not only claim Nepal as the birthplace of Buddha but should practice His teachings. Being the birthplace of the Buddha, his teachings should be offered prominent access throughout the country so that both individual and community can benefit from the teachings. Many viewed the exposure to the teachings of the Buddha, particularly morality and meditation, as a lasting solution to the current problems the country is facing due to rapid decline in ethics and the moral values among leaders, bureaucrats and the private sectors.

They shared a view that the teachings of the Buddha will offer ways for authentic self-reflection and by following His path one can become a responsible human-being full of love and compassion, minus greed and misconduct. These responsible citizens of the country only can bring positive changes to the country. Hence, the politicians, decision-makers, bureaucrats, businessmen, and stakeholders from all walks of life should be provided the opportunity to be familiar with His teachings, particularly morality, meditation and the law of karma so that they can play a role in the mission to make Nepal prosperous. Moreover, it is not only Nepal, but the whole world could benefit from the teachings of non-violence and loving-kindness.

At the time when ethics and integrity are deteriorating everywhere, The Buddha's teachings should be made compulsory study for politicians, decision-makers and people from all walks of life. All the Buddhist (Mahayana, Vajrayana, and Theravada) and Non-Buddhist Nepalese people, including politicians, professionals, and non-professionals should be aware of the Gautama Buddha's teaching and its practical application to the communities. Respondents also recommended that Anapana and mindfulness techniques should be taught to the bureaucrats and politicians as stress management. 


\section{Lumbini as the Center for World Peace}

Likewise, respondents suggested developing Lumbini, the birthplace of the Buddha, as a site of meditation as well as a Center of Buddhist studies. Lumbini should be developed as the center for disseminating the message for world peace. It should be developed like Mecca and Medina in Saudi Arabia.

Furthermore, Nepal is so fortunate to be sanctified with Niglihawa, and Gotihawa the birthplaces of the previous Buddhas and many historic sites associated with the Buddha. These sites could have invaluable importance in promoting spiritual tourism. Nepal should develop a Buddhist circuit encompassing all these Buddhist sites and benefit from religious tourism.

\section{Conclusions}

The perception level of the intellectual circle in Nepal about the Buddha and His teachings is found to be not satisfactory. In the context when Buddhism is spreading all over the world, the level of awareness of professionals in the birthplace is quite low that 81 percent of the intellectuals are unaware of The Dhammapada, 72 percent of The Jataka Stories, $71 \%$ of the Noble Eightfold Path and $65 \%$ of meditation. Furthermore, $15 \%$ of the professionals are still unaware of the life story of the Buddha; likewise, 35\% are unaware of the Five Moral Precepts and 50\% about the Four Noble Truth. These figures, which reflect the perceptions of intellectuals on the basic teachings of the Buddha, are enough to understand the way the general public of Nepal conceive of Buddhism. Amritopadesh (2007), a Buddhist monthly, in its editorial uncovered an alarming fact supportive to these findings that the people from Lumbini, Devdaha, and Ramgram, the famed Buddhist heritage sites, were unaware of the Buddha Purnima, the day when Prince Siddhartha was born, enlightened and attended Mahaparinirwana.

However, almost all (94\%) of the respondents agreed that the Nepalese children should know about the Buddha and the teachings of the Buddha should be included in the school curriculum. Likewise, 99\% had the view that Nepal should 
benefit from the Buddha and his teachings. The potentials of Buddhism should be exploited in producing morally good and patriotic citizens. They have also suggested developing Lumbini as the center for world peace and Buddhist studies.

The demolition of the Rana Regime in 1951 made the situation favorable for Buddhism. The fourth World Buddhist Conference (1956) was held in Kathmandu with the participation of dignitaries from different countries, including the father of the Indian constitution, Dr. Ambedkar. It was the first international conference ever held in Nepal (Bajracharya, 2019, P. 39) and played an important role in introducing Nepal in an international forum at the time when Nepal was in urgent need of international recognition. Lumbini continued to be the center of the growing international attraction and it was Lumbini that put Nepal on the World Map as a "Zone Of Peace." Despite this, the Buddhist intellectuals have accused that the state of ignoring Buddhism. Lack of moral education in the curriculum has made Nepalese youths less responsive to their parents and community (Shakya, 2019, P: 61 ).

It is already more than a decade since Nepal declared herself as a secular country by the Constitution. Many respondents shared the view that Nepal while claiming to be the birthplace of the Buddha, should bring His teachings into practice. Being the birthplace of the Buddha, His teachings should be offered mass access throughout the country so that both individual, community and the entire country can benefit from such initiatives.

\section{References}

Bajracharya, M. (2019). Dharmodaya Sabha: A Historical Association. Dharmodaya Memorial. 12th National Buddhist Conference, 6 \& 7 April 2019. Besisahar, Lamjung, Nepal. P: $38-40$. 
Dutt, N. (1966). "Buddhism in Nepal". Bulletin of Tibetology. 3 (2): 27-45.

Education in Figures (2017) at a glance. Ministry of Education, Science, and Technology, Singadurbar, Kathmandu, Nepal. P: 3 to 4 .

Paudel, A. (2018). Buddhako Nagarikata (Citizenship of the Buddha). The Anandabhoomi, year 45, Number 12, P: 19 to 21.

Sancrityayan, R. Buddhacharya. 6th Edition (2018). Samyak Prakashan, New Delhi. P: 91.

Shakya, B. R. (2018). Dharma Prakritik Niyam ho (Dhamma is a law of nature). Sammyek Sandesh (Right message). National Bimonthly. Year 2, number 10, P; 17 -20.

Shakya, M. K. (2019). Journey to Happiness. Dongol Printers, Kalanki, Kathmandu, Nepal. P: 8 and 61.

Shakya, S. K. (1980). Wisdom in Buddhist Psychology. Synthetic Psychology Center, Tahachal, Kathmandu. P: 21.

Singh, R. (1997). Vipassana in Government - An Effective Instrument for Change and Reform, Vipassana Research Institute, Dhammagiri, Igatpuri - 422403 Maharashtra, India.

Thapa, S. (2001). History of Nepalese Buddhism: From Mythological Tradition to the Lichhavi period. Voice of History, Vol. XVI, No. 2, (Dec. 2001) P: 39

Udas, G. M. (2018). Buddha Dharmaprati Anudarwadiharuko Asahisnutako Prarambha, Wikas ra Parinam (Initiation of uncooperative behavior from the narrow-minded people to Buddhism: Development, and Result). Anandabhoomi, year 46, Number 5, P: 7 to 9.

Ven. Sujano, S. M. (2008). Theravada Buddhism in Modern Nepal. Lumbini Nepalese Buddha Dharma Society (UK) www.lumbini.org.uk 